Braun Shareholder of: AbbVie, BMS, Celgene, Chugai, Merck, Novartis, Pfizer, UCB, Grant/research support from: AbbVie, BMS, Celgene, Chugai, Merck, Novartis, Pfizer, UCB, Grant/research support from: Abbott, Bristol Myers Squibb, Celgene, Celltrion, Chugai, Johnson \& Johnson, MSD, Novartis, Pfizer, Roche, UCB Pharma, Grant/research support from: AbbVie, BMS, Celgene, Chugai, Merck, Novartis, Pfizer, UCB, Grant/research support from: Abbvie (Abbott), Amgen, Baxter, Biogen, BMS, Boehringer, Celgene, Celltrion, Centocor, Chugai, Hexal, Janssen, Lilly, Medac, MSD (Schering-Plough), Mylan, Mundipharma, Novartis, Pfizer (Wyeth, Hospira), Roche, Sanofi-Aventis and UCB, Consultant for: Abbvie (Abbott), Amgen, Baxter, Biogen, BMS, Boehringer, Celgene, Celltrion, Centocor, Chugai, Hexal, Janssen, Lilly, Medac, MSD (Schering-Plough), Mylan, Mundipharma, Novartis, Pfizer (Wyeth, Hospira), Roche, Sanofi-Aventis and UCB, Consultant for: AbbVie, BMS, Celgene, Chugai, Merck, Novartis, Pfizer, UCB, Consultant for: Abbott, Bristol Myers Squibb, Celgene, Celltrion, Chugai, Johnson \& Johnson, MSD, Novartis, Pfizer, Roche, UCB Pharma, Speakers bureau: AbbVie, BMS, Celgene, Chugai, Merck, Novartis, Pfizer, UCB, Speakers bureau: Abbvie (Abbott), Amgen, Baxter, Biogen, BMS, Boehringer, Celgene, Celltrion, Centocor, Chugai, Hexal, Janssen, Lilly, Medac, MSD (Schering-Plough), Mylan, Mundipharma, Novartis, Pfizer (Wyeth, Hospira), Roche, Sanofi-Aventis and UCB, Speakers bureau: AbbVie, BMS, Celgene, Chugai, Merck, Novartis, Pfizer, UCB DOI: 10.1136/annrheumdis-2019-eular.2419

\section{FRI0102 GOLIMUMAB IMPROVES WORK PRODUCTIVITY AND ACTIVITY AND QUALITY OF LIFE IN PATIENTS WITH RHEUMATOID ARTHRITIS (RA), ANKYLOSING SPONDYLITIS (AS) AND PSORIATIC ARTHRITIS (PSA): FINAL RESULTS FROM A NON-INTERVENTIONAL STUDY IN GERMANY (GO-ART)}

Ines Klaudius ${ }^{1}$, Klaus Krueger ${ }^{2}$, Sven Remstedt ${ }^{3}$, Astrid Thiele ${ }^{4} .{ }^{1}$ MSD Sharp and Dohme GmbH, Haar, Germany; ${ }^{2}$ Praxiszentrum St. Bonifatius, Munich, Germany; ${ }^{3}$ Rheuma Praxis, Berlin, Germany, ${ }^{4}$ Krankenhaus St. Josef, Wuppertal, Germany

Background: Golimumab (GLM) has shown its efficacy and tolerability in various randomized clinical trials. Systemic data for GLM regarding health-economic parameters in daily clinical practice are essential not only for pharmaceutical companies but also for cost-benefit analyses in Germany.

Objectives: This prospective NIS was designed to evaluate the impact of GLM therapy on work productivity and activity as well as Quality of Life (QoL) in patients with RA, AS or PsA in Germany under routine settings over an observation period of 12 months, plus an additional voluntary extension period of 12 months (total 24 months) to collect long-term data on health economic parameters.

Methods: GO-ART was an observational prospective study on patients with RA, AS or PsA (biologic-naïve and biologic-experienced) who started treatment with GLM at 63 sites of Germany.

The primary endpoint was the change in work productivity/activity impairment as measured by Work Productivity and Activity Impairment (WPAI) questionnaire from baseline, measured primarily at month 3 and secondarily at months 6,12 and 24 .

As secondary endpoint the change in quality of life (RAQoL for RA patients, ASQoL for AS patients and NAPPA-QoL for PsA patients) was assessed.

Results: 748 patients $(R A=250, P s A=249, A S=249)$ started GLM therapy. The primary efficacy endpoint was analyzed in the modified intention-totreat (mITT) subset of 493 patients $(R A=158, P s A=157, A S=178)$ with full-time or part-time employment at baseline (mITTe).

A total of 348 patients entered the additional 12-month observation period, of which 303 completed the 24-month assessment.

By 3 months after initiation of Golimumab treatment, a marked improvement was seen in all 4 WPAI domain scores ("absenteeism" (time off work), "presenteeism" (on-the-job productivity), "total work productivity impairment" (TWPI), and "activity impairment") in daily living because of patient's health problems related to RA, PSA or AS, as shown in Table 1 (all $\mathrm{p}$-values $<0.05$ ).

The statistically significant improvements in the mean WPAI domain scores were maintained over the 24-month observation period in all 3 indications with a higher treatment effect regarding "activity impairment" and "presenteeism" compared to "absenteeism" (Table 1).

Quality of life improved significantly $(p<0.0001)$ from baseline at month 3 , 6,12 and 24 in patients with RA (RAQoL), AS (ASQoL) and PsA (NAPPA-QoL) based on questionnaire data of 237 RA patients (RAmITT), 228 AS patients (AS-mITT) and 235 PsA patients (PsA-mITT) indicating a clinically relevant improvement.
Conclusion: Treatment with GLM provided sustained improvement in WPAI and QoL in patients with RA, PsA and AS over the observational period of 24 months.

All scores of the WPAI showed a significant $(p<0.05)$ reduction in mean score values in each indication.

GLM leads to an improvement of work productivity and daily activities in patients already within the first 3 months of treatment.

Table 1:

WPAI - Changes in the 4 domain scores from baseline to Months 3, 12 and 24 (mITTe)

\begin{tabular}{|c|c|c|c|c|c|}
\hline Timepoint & Statistics & $\begin{array}{l}\text { a work productivity } \\
\text { impairment }\end{array}$ & Absenteeism & Presenteeism & $\begin{array}{c}\text { Activity } \\
\text { impairment }\end{array}$ \\
\hline \multicolumn{6}{|c|}{ RA patients (mITTe: N=158) } \\
\hline Vo (baseline) & $\begin{array}{l}\text { N } \\
\text { Mean } \\
\text { SD }\end{array}$ & $\begin{array}{c}108 \\
4468 \\
27.60\end{array}$ & $\begin{array}{r}135 \\
111.9 \\
30.80\end{array}$ & $\begin{array}{l}113 \\
46.0 \\
27.76\end{array}$ & $\begin{array}{l}154 \\
50.9 \\
28.36\end{array}$ \\
\hline 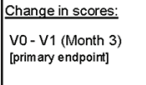 & $\begin{array}{l}\mathrm{N} \\
\text { Mean } \\
\text { SD } \\
\text { p-value }\end{array}$ & $\begin{array}{c}78 \\
-11.3 \\
23.77 \\
<0.0001^{\circ}\end{array}$ & $\begin{array}{c}110 \\
-5.8 \\
29.37 \\
0.0422^{\circ}\end{array}$ & $\begin{array}{r}83 \\
-12.5 \\
23.00 \\
<0.001^{\circ}\end{array}$ & $\begin{array}{r}133 \\
-13.9 \\
26.77 \\
<0.0001^{\natural}\end{array}$ \\
\hline vo - v3 (Month 12) & $\begin{array}{l}\text { N } \\
\text { Mean } \\
\text { SD } \\
\text { p-value }\end{array}$ & $\begin{array}{c}67 \\
-13.2 \\
23.40 \\
<0.0001^{3}\end{array}$ & $\begin{array}{c}89 \\
\text {-8.8. } \\
35.51 \\
0.0128^{\mathrm{b}}\end{array}$ & $\begin{array}{l}75 \\
-12.7 \\
22.08 \\
<2.0001^{10}\end{array}$ & $\begin{array}{l}114 \\
-15.2 \\
24.23 \\
<0.0001^{\circ}\end{array}$ \\
\hline vo - V6 (Month 24) & $\begin{array}{l}\text { N } \\
\text { Mean } \\
\text { SD } \\
\text { p-value }\end{array}$ & $\begin{array}{c}43 \\
-13 \\
25.74 \\
0.0012^{9}\end{array}$ & $\begin{array}{c}55 \\
-7.8 \\
30.73 \\
0.0647^{\circ}\end{array}$ & $\begin{array}{c}45 \\
-12.2 \\
2.6 .10 \\
0.0030^{\circ}\end{array}$ & $\begin{array}{r}-67 \\
-18.4 \\
26.32 \\
<0.0001^{9}\end{array}$ \\
\hline \multicolumn{6}{|c|}{ PSA patients (mITTe: N=157) } \\
\hline $\begin{array}{l}\text { vo (baseline) } \\
\text { Chance in scores: }\end{array}$ & $\begin{array}{l}\text { N } \\
\text { Mean } \\
\text { SD }\end{array}$ & $\begin{array}{l}114 \\
35.0 \\
27.77\end{array}$ & $\begin{array}{c}137 \\
12.9 \\
30.87\end{array}$ & $\begin{array}{l}115 \\
33.4 \\
26.42\end{array}$ & $\begin{array}{l}153 \\
43.2 \\
28.45\end{array}$ \\
\hline $\begin{array}{l}\text { vo- v1 (Month 3) } \\
\text { [primary endpoirt]) }\end{array}$ & $\begin{array}{l}\text { Nean } \\
\text { Mean } \\
\text { SO p-value }\end{array}$ & $\begin{array}{c}81 \\
-13.8 \\
25.02 \\
<0.0001^{3}\end{array}$ & $\begin{array}{c}109 \\
-4.9 \\
28.33 \\
0.0449^{\circ}\end{array}$ & $\begin{array}{c}85 \\
-15.4 \\
25.98 \\
<0.0001^{\circ}\end{array}$ & $\begin{aligned} & 128 \\
&-17.4 \\
& 30.44 \\
&<0.0001^{\mathrm{D}}\end{aligned}$ \\
\hline Vo - V3 (Month 12) & $\begin{array}{l}\text { N } \\
\text { Mean } \\
\text { So } \\
\text { p-value }\end{array}$ & $\begin{array}{c}77 \\
-10.6 \\
30.04 \\
0.0046^{\circ}\end{array}$ & $\begin{array}{c}99 \\
-4.6 \\
30.62 \\
0.2028^{\circ}\end{array}$ & $\begin{array}{l}80 \\
-21.72 \\
27.82 \\
0.0001^{\circ}\end{array}$ & $\begin{array}{r}118 \\
-18.3 \\
30.28 \\
<0.0001^{3}\end{array}$ \\
\hline V0 - V6 (Month 24) & $\begin{array}{l}\text { N } \\
\text { Mean } \\
\text { So } \\
\text { p-value }\end{array}$ & $\begin{array}{r}39 \\
-39 \\
28.59 \\
0.0472^{2}\end{array}$ & $\begin{array}{c}48 \\
-1.9 \\
33.156 \\
0.6084^{4}\end{array}$ & $\begin{array}{r}41 \\
-16.5 \\
26.84 \\
0.0003^{3}\end{array}$ & $\begin{array}{r}63 \\
-23.4 \\
31.36 \\
<0.0001^{3}\end{array}$ \\
\hline \multicolumn{6}{|c|}{ AS patients (mITTe: $N=178$ ) } \\
\hline vo (baseline) & $\begin{array}{l}\text { N } \\
\text { Mean } \\
\text { SD }\end{array}$ & $\begin{array}{c}136 \\
48.2 \\
28.08\end{array}$ & $\begin{array}{c}160 \\
160 \\
29.05\end{array}$ & $\begin{array}{l}142 \\
45.9 \\
26.74\end{array}$ & $\begin{array}{l}177 \\
52.1 \\
25.87\end{array}$ \\
\hline $\begin{array}{l}\text { Vo- V1 (Month 3) } \\
\text { [primary endpoint] }\end{array}$ & $\begin{array}{l}\text { N } \\
\text { Mean } \\
\text { SO } \\
\text { p-value }\end{array}$ & $\begin{array}{c}104 \\
-16.9 \\
26.92 \\
<0.0001^{10}\end{array}$ & $\begin{array}{c}135 \\
-8.9 \\
30.73 \\
0.0001^{1}\end{array}$ & $\begin{aligned} & 111 \\
&- 15.8 \\
& 24.66 \\
&<0.001^{\circ}\end{aligned}$ & $\begin{array}{r}162 \\
-18.3 \\
26.43 \\
<0.0001^{6}\end{array}$ \\
\hline vo - V3 (Month 12) & $\begin{array}{l}\text { N } \\
\text { Mean } \\
\text { SD } \\
\text { p-value }\end{array}$ & $\begin{array}{c}93 \\
-16.8 \\
31.92 \\
<0.0001^{3}\end{array}$ & $\begin{array}{c}120 \\
-6.1 \\
31.46 \\
0.0141^{1}\end{array}$ & $\begin{array}{r}100 \\
-16.1 \\
30.45 \\
<0.0001^{3}\end{array}$ & $\begin{array}{c}130 \\
-28.8 \\
28.77 \\
<0.001^{3}\end{array}$ \\
\hline Vo - V G (Month 24) & $\begin{array}{l}\text { N } \\
\text { Mean } \\
\text { SD } \\
\text { p-value }\end{array}$ & $\begin{array}{c}46 \\
-24.7 \\
32.71 \\
<0.0001^{3}\end{array}$ & $\begin{array}{c}64 \\
-14.1 \\
33.29 \\
0.0002^{\mathrm{p}}\end{array}$ & $\begin{array}{c}50 \\
-22.0 \\
28.64 \\
<0.0001^{3}\end{array}$ & $\begin{array}{r}72 \\
-28.3 \\
29.79 \\
<0.0001^{\circ}\end{array}$ \\
\hline
\end{tabular}

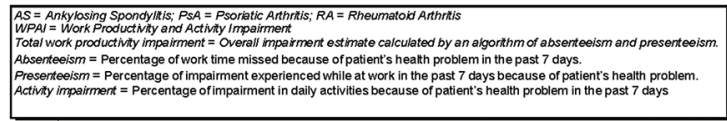

t-test; Wicoxon Signed rank test

Disclosure of Interests: Ines Klaudius Employee of: MSD Sharp \& Dohme GmbH, Klaus Krueger: None declared, Sven Remstedt: None declared, Astrid Thiele Consultant for: Biogen, Celgene, Chugai, Hexal, Janssen, Lilly, MSD, Novartis, Pfizer, UCB

DOI: 10.1136/annrheumdis-2019-eular.1824

\section{FRI0103 BENEFIT STUDY: A PAN-EUROPEAN OBSERVATIONAL STUDY TO EVALUATE REAL-WORLD EFFECTIVENESS OF SB4 FOLLOWING TRANSITION FROM ORIGINATOR ETANERCEPT (ETN) IN PATIENTS WITH RHEUMATOID ARTHRITIS (RA) OR AXIAL SPONDYLOARTHRITIS (AXSPA)}

Klaus Krueger ${ }^{1}$, Carlo Selmi ${ }^{2,3}$, Alain Cantagrel ${ }^{4}$, Abad Hernández ${ }^{5}$, Ulrich Freudensprung ${ }^{6}$, Mourad Farouk Rezk ${ }^{6}$, Janet Addison ${ }^{7} .{ }^{1}$ Medical Centre of Rheumatology, Munich, Germany, ${ }^{2}$ Humanitas Research Centre, Milan, Italy; ${ }^{3}$ University of Milan, Milan, Italy; ${ }^{4} \mathrm{Center}$ of Rheumatology of $\mathrm{CHU}$, Toulouse France; ${ }^{5}$ FEA Reumatología, Hospital Virgen del Puerto, Cáceres, Spain; ${ }^{6}$ Biogen International GmbH, Baar, Switzerland; ' ${ }^{7}$ Biogen Idec Ltd, Maidenhead, United Kingdom

Background: Having demonstrated bioequivalence and similar efficacy, safety and immunogenicity as the originator, SB4 is approved in the EU 
as an ETN biosimilar. There is limited evidence on outcomes of transition from originator to biosimilar in a multi-country real-world setting.

Objectives: To provide real-world evidence on outcomes of transition from ETN to SB4 in routine clinical practice at EU sites.

Methods: Eligible patients had RA or axSpA and had initiated SB4 in routine clinical practice following a minimum of 6 months treatment with a stable dose of originator ETN, at clinics in France, Germany, Italy, and Spain. Data were captured from patient records prospectively and/or retrospectively for 6 months following transition. Outcome measures include clinical characteristics, disease scores (DAS-28 for RA, BASDAl for axSpA) and clinical management.

Results: Analysis of 533 eligible patients (347 RA, 186 axSpA) demonstrated no clinically significant difference in disease score from baseline to 6 months post-transition; mean individual change was $0.0(95 \% \mathrm{Cl}$ $0.1,0.1)$ and $0.0(95 \% \mathrm{Cl}-0.3,0.2)$ at 6 months post-transition in RA and axSpA subjects respectively. Regarding dose regimen, $73.5 \%$ and $63.4 \%$ of RA and axSpA subjects transitioned from ETN $50 \mathrm{mg}$ QW to SB4 50mg QW; by 6 months post-transition, $73.5 \%$ and $63.4 \%$ of subjects were receiving SB4 50mg QW.

Table 1. Patient baseline characteristics and disease scores at 6 months post-transition

\begin{tabular}{|c|c|c|c|c|}
\hline & \multicolumn{2}{|c|}{$\mathrm{RA}(\mathrm{N}=347)$} & \multicolumn{2}{|c|}{$\operatorname{AxSpA}(\mathrm{N}=186$} \\
\hline & $\begin{array}{l}\text { Mean } \\
\text { (SD) }\end{array}$ & $\begin{array}{l}\text { Q1, } \\
\text { Q3 }\end{array}$ & $\begin{array}{c}\text { Mean } \\
\text { (SD) }\end{array}$ & $\begin{array}{l}\text { Q1, } \\
\text { Q3 }\end{array}$ \\
\hline Age in years & $\begin{array}{c}60.8 \\
(11.87)\end{array}$ & $\begin{array}{l}53.0 \\
69.0\end{array}$ & $\begin{array}{c}50.2 \\
(13.41)\end{array}$ & $\begin{array}{l}40.0 \\
61.0\end{array}$ \\
\hline Women n (\%) & $\begin{array}{c}255 \\
(73.5)\end{array}$ & - & $\begin{array}{c}48 \\
(25.8)\end{array}$ & - \\
\hline Duration of disease, years & $\begin{array}{l}14.7 \\
(9.41)\end{array}$ & $\begin{array}{l}7.3 \\
21.0\end{array}$ & $\begin{array}{c}12.9 \\
(10.51)\end{array}$ & $\begin{array}{l}5.1 \\
17.4\end{array}$ \\
\hline BMI & $\begin{array}{l}27.5 \\
(5.64)\end{array}$ & $\begin{array}{l}23.3 \\
30.4\end{array}$ & $\begin{array}{l}27.5 \\
(3.78)\end{array}$ & $\begin{array}{r}24.1 \\
30.5\end{array}$ \\
\hline csDMARD* concomitant to SB4 n\% & $\begin{array}{c}186 \\
(53.6)\end{array}$ & - & $\begin{array}{c}28 \\
(15.1)\end{array}$ & - \\
\hline NSAID ${ }^{\star \star}$ concomitant to SB4 n\% & $\begin{array}{c}48 \\
(13.8)\end{array}$ & - & $\begin{array}{c}39 \\
(21.0)\end{array}$ & - \\
\hline & $\begin{array}{c}\text { Mean } \\
\text { (SD) }\end{array}$ & $\begin{array}{c}95 \% \\
\mathrm{Cl}\end{array}$ & $\begin{array}{c}\text { Mean } \\
\text { (SD) }\end{array}$ & $\begin{array}{c}95 \% \\
\mathrm{Cl}\end{array}$ \\
\hline DAS-28 at transition to SB4 $(n=329)$ & $\begin{array}{c}2.0 \\
(0.83)\end{array}$ & $\begin{array}{l}1.9 \\
2.1\end{array}$ & - & - \\
\hline DAS-28 at 6 months post-transition to SB4 $(n=242)$ & $\begin{array}{c}2.1 \\
(0.85)\end{array}$ & $\begin{array}{l}2.0 \\
2.2\end{array}$ & - & - \\
\hline $\begin{array}{l}\text { DAS-28 Individual change from baseline to } 6 \\
\text { months post-transition to SB4 }(n=237)\end{array}$ & $\begin{array}{c}0.0 \\
(0.81)\end{array}$ & $\begin{array}{c}-0.1 \\
0.1\end{array}$ & - & - \\
\hline BASDAI at transition to SB4 $(n=173)$ & - & - & $\begin{array}{c}2.5 \\
(1.94)\end{array}$ & $\begin{array}{l}2.2, \\
2.8\end{array}$ \\
\hline BASDAl at 6 months post-transition to SB4 $(n=124)$ & - & - & $\begin{array}{c}2.3 \\
(1.82)\end{array}$ & $\begin{array}{l}2.0 \\
2.7\end{array}$ \\
\hline $\begin{array}{l}\text { BASDAI Individual change from baseline to } 6 \\
\text { months post-transition to SB4 }(n=121)\end{array}$ & - & - & $\begin{array}{c}0.0 \\
(1.19)\end{array}$ & $\begin{array}{r}-0.3 \\
0.2\end{array}$ \\
\hline
\end{tabular}

DAS-28 Disease Activity Score 28; BASDAI Bath Ankylosing Spondylitis Disease Activity Index; BMI body mass index; SD standard deviation; Q1 $1^{\text {st }}$ quartile, Q3 $3^{\text {rd }}$ quartile; $\mathrm{Cl}$ Confidence Interval; * ${ }^{\circ}$ conventional synthetic disease-modifying antirheumatic drug; ${ }^{* *}$ nonsteroidal anti-inflammatory drug

Conclusion: Patients with stable RA or axSpA who transitioned from originator ETN to SB4 maintained clinical response at 6 months post-transition. Most patients transitioned to the same dose regimen of biosimilar as they had received for the originator, remaining largely unchanged at 6 months, supporting ease and effectiveness of transition.

Biogen International $\mathrm{GmbH}$ sponsored and funded this study.

Disclosure of Interests: Klaus Krueger: None declared, Carlo Selmi Grant/research support from: Abbvie, Janssen, MSD, Novartis, Pfizer, Consultant for: Abbvie, Alfa-Sigma, Biogen, BMS, Celgene, Eli-Lilly, GSK, Janssen, Merck Sharp and Dohme, Novartis, Pfizer, Roche, Sanofi-Genzyme, YCB, Speakers bureau: Abbvie, Alfa-Sigma, Biogen, BMS, Celgene, Eli-Lilly, GSK, Janssen, Merck Sharp and Dohme, Novartis, Pfizer, Roche, Sanofi-Genzyme, YCB, Alain Cantagrel Grant/research support from: Abbvie, Chugai, MSD, Pfizer, UCB, Consultant for: BMS, Chugai, Janssen, Lilly France, Médac, MSD France, Novartis, Pfizer, Roche, Sandoz, Sanofi Aventis, UCB, Speakers bureau: Abbvie, Biogen, BMS, Celgene, Chugai, Janssen, Lilly France, MSD France, Nordic-Pharma, Novartis, Pfizer, Roche, Sanofi, UCB, Abad Hernández: None declared, Ulrich Freudensprung Shareholder of: Biogen, Employee of: Biogen, Mourad Farouk Rezk Shareholder of: Biogen, Employee of: Biogen, Janet Addison Shareholder of: Biogen, Employee of: Biogen

DOI: 10.1136/annrheumdis-2019-eular.5665

\section{FRI0104}

A LARGE REAL WORLD, LONG TERM SAFETY STUDY OF PATIENTS WITH INFLAMMATORY RHEUMATIC DISEASES TREATED WITH INFLIXIMAB BIOSIMILAR (CT-P13): POOLED ANALYSIS OF FOUR GLOBAL POSTMARKETING STUDIES

Kyungmin Baek ${ }^{1}$, Yoon Jee Lee ${ }^{1}$, Sujin Lee ${ }^{1}$, Houng Kim², Seulgi Lee ${ }^{1}$, Jeong Eun Park ${ }^{1}$, SangJoon Lee ${ }^{1}{ }^{1}$ Celltrion Inc, Incheon, Korea, Rep. of (South Korea); ${ }^{2}$ Celltrion Healthcare Co, Ltd, Incheon, Korea, Rep. of (South Korea)

Background: CT-P13 was the first approved biosimilar monoclonal antibody globally and is currently marketed in 88 countries, including the European Union (EU) and the United States (US). Since approval, 4 observational prospective cohort studies have been conducted in the EU, Canada and Korea to assess long term safety of CT-P13 in patients with Rheumatoid arthritis (RA), ankylosing spondylitis (AS), psoriatic arthritis (PsA) and psoriasis (PSO). Safety data from the 4 studies were pooled and analysed.

Objectives: To evaluate the long-term safety of CT-P13 in patients with RA, AS, PsA and PSO in global real world, post-marketing studies Methods: Safety data from patients registered in the 4 observational studies (KOREA PMS, CT-P13 4.2, CT-P13 4.4, and PERSIST) have been collected after marketing authorisation was granted. The incidence of Adverse Events of Special Interests (AESIs) from subjects with RA, AS, PsA and PsO who were treated at least 1 dose of CT-P13 with the data cut point of Dec27, 2017 were analysed.

Results: A total of 1579 patients were treated with at least 1 dose of CT-P13 across the 4 studies $(\mathrm{RA}=670 ; \mathrm{AS}=819 ; \mathrm{PsA} / \mathrm{PsO}=90$ ). Mean age (years) of patients per RA, AS and PsA/PSO indication was 54.5, 40.3 and 52.9, respectively. Average exposure duration (days) to CT-P13 in patients with RA, AS and PsA/PSO was 280.3, 254.0 and 322.1 , respectively, and the mean maximum dose of CT-P13 $(\mathrm{mg} / \mathrm{kg})$ with RA, AS and PsA/PSO patients was 3.77, 4.51 and 4.31, respectively. Treatment emergent adverse events (TEAEs) were reported in $50.15 \%, 37.73 \%$ and $26.67 \%$ for RA, AS and PsA/PSO, respectively. Incidence of TEAEs in RA indication is consistent with the historical rate in this population. Treatment emergent serious adverse events (TESAEs) were reported for $12.39 \%, 4.52 \%$ and $3.33 \%$ for RA, AS and PSA/PSO patients, respectively. Incidence of TEAEs leading to discontinuation were $8.81 \%, 3.42 \%$ and $7.78 \%$ for RA, AS and PsA/PSO. Two deaths and 1 death were reported among RA and AS patients, respectively. The causes of death in RA patients were acute respiratory distress syndrome (ARDS) and bronchopneumonia; the cause of death in the AS patient was unknown. AESIs of CT-P13 were analysed in safety population who were treated with CT-P13 at least once by the data cut point. No events of serum sickness, haematologic malignancy, demyelinating disorder, sarcoidosis/sarcoidosis-like reaction were reported.

Table 1. Incidence of AESIs

\begin{tabular}{lccc}
\hline $\begin{array}{l}\text { AESIs/ } \\
\text { Number of patients (\%) }\end{array}$ & $\begin{array}{c}\mathrm{RA} \\
\mathrm{N}=670\end{array}$ & $\begin{array}{c}\mathrm{AS} \\
\mathrm{N}=819\end{array}$ & $\begin{array}{c}\mathrm{PsA} / \mathrm{PSO} \\
\mathrm{N}=90^{[1]}\end{array}$ \\
\hline $\begin{array}{l}\text { Serious infection including Tuberculosis (TB) } \\
\text { Active Tuberculosis }\end{array}$ & $\begin{array}{c}27(4.03 \%) \\
\text { Acute hypersensitivity }\end{array}$ & $17(2.08 \%)$ & $1(1.11 \%)$ \\
Haematologic reaction & $1(0.45 \%)$ & $5(0.61 \%)$ & 0 \\
Systemic Lupus erythematosus/ & $8(1.19 \%)$ & $1(0.12 \%)$ & 0 \\
Lupus-like syndrome & 0 & $5(0.61 \%)$ & $2(2.22 \%)$ \\
Non-Haematologic Malignancy & & 0 & $1(1.11 \%)$ \\
Hepatobiliary Event & $6(0.90 \%)$ & 0 & 0 \\
HBV reactivation & $22(3.28 \%)$ & $34(4.15 \%)$ & 0 \\
Congestive Heart Failure & 0 & $1(0.12 \%)$ & 0 \\
\hline & 0 & $1(0.12 \%)$ & 0 \\
\hline
\end{tabular}

${ }^{[1]} 6$ patients of $\mathrm{PSO}$ were analysed with PsA patients

Conclusion: The results of this analysis show that treatment with CT-P13 is well tolerated in patients with RA, AS, PsA and PSO in the real world setting. Incidence of all AESIs including serious infection and TB are comparable to historical data in literatures ${ }^{[1][2]}$ and originator Infliximab EU product information.

\section{REFERENCES:}

[1] Vander Cruyssen, et al. (2010), Seven-year follow-up of infliximab therapy in rheumatoid arthritis patients with severe long-standing refractory disease: attrition rate and evolution of disease activity.

[2] Delabaye, et al. (2010), 74-week follow-up of safety of infliximab in patients with refractory rheumatoid arthritis. 